\title{
Gastric Acid Secretion in Chronic Renal Failure
}

\author{
P. S. VENTKATESWARAN, A. JEFFERS, A. G. HOCKEN
}

British Medical fournal, 1972, 4, 22-23

\section{Summary}

Contrary to the small amount of published evidence, but in accordance with clinical impression, we have found an increased incidence of peptic ulceration in people with chronic renal failure. Hyperacidic secretion in response to a standard pentagastrin test occurs in patients established on long-term dialysis treatment. The traditional liability of azotaemic patients to peptic ulceration seems not to be decreased by adequate long-term dialysis and indeed may be worsened.

\section{Introduction}

Gastrointestinal bleeding is a recognized complication of renal failure, traditionally being associated with peptic ulceration. Gastrointestinal blood loss is contributory to the anaemia of chronic renal failure. The radiological findings of duodenal or gastric ulceration or both in three patients, all of whom were examined because of symptoms of or proved gastrointestinal blood loss, from a population of 16 patients maintained on longterm haemodialysis indicated the necessity for the present investigations. Examination was by pentagastrin stimulation and barium meal.

\section{Materials and Methods}

Maximum gastric acid secretion was assessed by measuring the peak acid output as described by Johnston and Jepsom (1967). Twenty-four subjects were studied, eight normal controls and 16 patients with established chronic renal failure, 10 of whom were receiving long-term haemodialysis. Control subjects were selected from patients convalescing after acute illness with no evidence of disease of the gastrointestinal tract or urinary system. All were adults who gave consent to the investigations after the purpose of the exercise had been explained, within the context of contributing nothing to their own illness and treatment.

\section{PENTAGASTRIN STIMULATION}

After an overnight fast a nasogastric tube (Ray X Porges) was passed into the pyloric antrum. The position of the tip was adjusted under $x$-ray control using image-intensified fluoroscopy. Continuous gastric suction was applied by a Roberts pump at a subatmospheric pressure of $2-3 \mathrm{~cm} \mathrm{Hg}$. Tubal patency was maintained by the passage of air every few minutes. The resting juice was collected for 15 minutes and then discarded. Pentagastrin was then given intramuscularly at a dose of $6 \mu \mathrm{g} / \mathrm{kg}$ body weight. Gastric aspirate was collected over two periods, up to 10 minutes and then 10-30 minutes after injection of pentagastrin. The volume and $\mathrm{pH}$ of both specimens were measured, the latter by titration against $0.01 \mathrm{NaOH}$ to $\mathrm{pH} 7.0$ with direct-reading $\mathrm{pH}$ meter (Electronic Instruments Limited). Accordingly the rate of peak acid output in $\mathrm{mEq} / \mathrm{hr}$ was calculated. Department of Nephrology, Hull Royal Infirmary (Sutton), Hull,
East Yorkshire

P. S. VENKATESWARAN, M.B., M.R.C.P., Registrar (Present appointment: Senior Registrar, United Manchester Hospitals, Monsall Hospital, Manchester)

A. JEFFERS, I.R.C.P. \& S.I., Senior House Officer

A. G. HOCKEN, M.B., M.R.C.P., Physician
All the patients with renal disease had a barium-meal examination for evidence of peptic ulceration. The control group was not studied radiologically.

\section{Results}

The reproducibility of the $6 \mu \mathrm{g} / \mathrm{kg}$ body weight dose of pentagastrin as a "maximal" stimulus, whether administered subcutaneously or intramuscularly, has been established (Multicentre Pilot Study, 1967; Johnston and Jepsom, 1967). The peak acid output in the control subjects was found to be within the range given by Johnston and Jepsom (1967), whose method we emulated. Their mean peak acid output in normals was higher than ours, but their controls were males, who are known to have a greater maximum response than females (Baron, 1963). Pentagastrin stimulation in unselected control subjects yielded a normal range of 6.4 to $30.8 \mathrm{mEq} / \mathrm{hr}$ (mean 18.1).

The results of pentagastrin stimulation and barium-meal studies related to duration of treatment are summarized in the Table. The range of peak acid output levels in patients with

TABLE I-Barium-meal Findings related to Duration of Long-term Dialysis Treatment and Peak Gastric Acid Output

\begin{tabular}{|c|c|c|c|c|}
\hline Case No. & Barium-meal Report & $\begin{array}{c}\text { Duration of } \\
\text { Treatment at } \\
\text { Time of } \\
\text { Barium-meal } \\
\text { Examination } \\
\text { (Months) }\end{array}$ & $\begin{array}{c}\text { Peak Acid } \\
\text { Output } \\
\text { (mEq/hr) }\end{array}$ & $\begin{array}{c}\text { Duration of } \\
\text { Dialysis at } \\
\text { Time of } \\
\text { Pentagastrin } \\
\text { Test } \\
\text { (Months) }\end{array}$ \\
\hline $\begin{array}{c}1 \\
2 \\
3 \\
4 \\
5 \\
6^{*} \\
7 \\
8 \\
9 \\
10 \\
11 \\
6^{*} \\
12 \\
13^{*} \\
14 \\
15 \\
16 \\
13^{*}\end{array}$ & $\begin{array}{l}\text { Normal } \\
\text { Normal } \\
\text { Irritable } \\
\text { Irritable } \\
\text { Duodenal ulcer } \\
\text { Duoderal ulcer } \\
\text { Normal } \\
\text { Normal } \\
\text { Normal } \\
\text { Scarred } \\
\text { Normal } \\
\text { Gastric ulcer } \\
\text { Normal } \\
\text { Duodenal ulcer } \\
\text { Normal } \\
\text { Normal } \\
\text { Normal } \\
\text { Scarred }\end{array}$ & $\begin{array}{r}\text { 二 } \\
2 \\
3 \\
4 \\
7 \\
8 \\
10 \\
15 \\
15 \\
16 \\
17 \\
18 \\
23 \\
27 \\
30 \\
31\end{array}$ & $\begin{array}{l}3 \overline{35 \cdot 3} \\
31 \cdot 1 \\
40 \cdot 1 \\
3 \overline{39 \cdot 6} \\
27 \cdot 6 \\
41 \cdot 6 \\
18 \cdot 5 \\
26 \cdot 8 \\
= \\
\overline{7} \\
18 \cdot 3 \\
= \\
=\end{array}$ & $\begin{array}{r}16 \\
4 \\
4 \\
33 \\
9 \\
7 \\
11 \\
16 \\
= \\
32 \\
30 \\
=\end{array}$ \\
\hline
\end{tabular}

* Cases 6 and 13 had two barium-meal examinations, both with evidence of gastrointestinal blood loss between examinations.

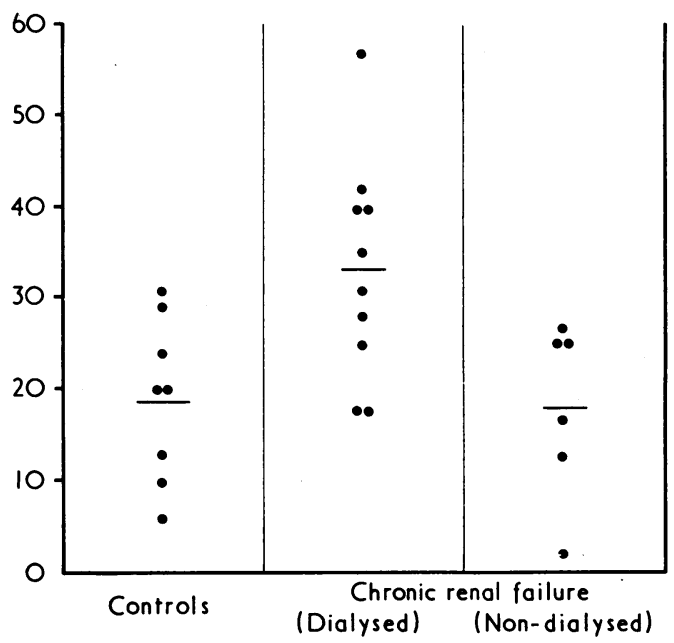

Peak acid output under pentagastrin stimulation of patients with chronic renal failure. Horizontal bars represent mean values. 
chronic renal failure who were established on dialysis programmes was $18 \cdot 1$ to $57 \cdot 3 \mathrm{mEq} / \mathrm{hr}$ with a mean rate of 33.6 .

The peak acid output of patients with stable chronic renal failure not on dialysis are compared with the preceding groups in the Figure.

\section{Discussion}

This study was provoked by three abnormal barium meals undertaken for gastrointestinal symptoms in patients on longterm dialysis. Among the remaining 13 patients on long-term dialysis three more were found to have abnormal barium studies. "Uraemic bleeding" from the gastrointestinal tract is recognized in renal failure. The excessive occurrence of peptic ulceration is not, and where anecdotally acknowledged (Hadjiyannakis et al., 1971) is said to be avoidable by "adequate and prompt haemodialysis." Peptic ulceration is a recognized and documented problem of renal transplantation (Moore and Hume, 1969; Hadjiyannakis et al., 1971) but obviously the immunological aspect clouds the picture. The only opinion which was based on investigatory evidence (Wiener et al., 1969) denied an increased incidence of chronic duodenal ulceration in patients receiving long-term dialysis.

Both direct and indirect peptic secretory studies in renal failure are not without ambiguity, but do not suggest an abnormally increased rate of gastric secretion either under normal circumstances or with histamine (Fillastre et al., 1965; Kiil and Enger, 1968), betazole (Goldstein et al., 1967; Schupak and Ferayorni 1968), or pentagastrin (Gordon et al., 1972) stimulation. However, Goldstein et al. (1967) commented that dialysis was associated with an augmented maximum response to betazole hydrochloride stimulation. Contrary to the statement of Gordon et al. (1972), who measured the secretion rate of hydrogen ion in their own investigation, the work of Fillastre et al. (1965) did not suggest an increase of hydrogen ion secretion rate in azotaemic patients. Fillastre's results indicated an increased hydrogen ion concentration of gastric secretion, but a decreased volume of juice. The appropriate calculations indicate a secretion rate of hydrogen ion in response to histamine stimulation comparable to their normal range.
The final problem is to consider the reality of the appearance of hyperacidity with establishment of dialysis (see Figure). Not only the phenomenon but the mechanism demands investigation. If the raised serum gastrin level as a result of loss of renal metabolism of that peptide is not the source, as doubted by Korman et al. (1971, 1972), one must consider the role of calcium. Serum calcium levels seem well related in some cases to gastric activity (Barreras and Donaldson, 1967), but the reliability of this association is questioned by the data of Gordon et al. (1972). It is, however, well recognized that there are areas of calcium and bone metabolism which are a complete enigma (Kerr and Hocken, 1971), and this line of investigation is being pursued.

We are grateful to the control subjects for their submission to examination, and to Sisters A. Scurrell and J. Barker for help in the management thereof, as well as to the department of radiology, and Dr. M. J. Imrie in particular, for their interested help and willing co-operation.

\section{References}

Baron, J. H. (1963). Gut, 4, 136.

Barreras, R. F., and Donaldson, R. M. (1967). New England fournal of Medicine, 276, 1122.

Fillastre, J. P., Blaise, P., Ardaillou, R., and Richet, G. (1965). Revue Franfaise d'Etudes Cliniques et Biologiques, 10, 180.

Goldstein, H., Murphy, D., Sokol, A., and Rubini, M. E. (1967). Archives of Internal Medicine, 120, 645 .

Gordon, E. M., Johnson, A. G., and Willians, G. (1972). Lancet, 1, 226. Hadjiyannakis, E. J., Evans, D. B., Smellie, W. A. B., and Calne, R. Y. (1971). Lancet, 2, 781.

Johnston, D., and Jepsom, K. (1967). Lancet, 2, 585

Kerr, D. N. S., and Hocken, A. G. (1971). Proceedings of the European Dialysis and Transplant Association, 8, 159.

Kiil, F., and Enger, E. (1968). Scandinavian fournal of Clinical and Laboratory Investigation, 22, 277.

Korman, M. G., Strickland, R. G., and Hansky, J. (1971). British Medical Fournal, 2, 16 .

Korman, M. G., Laver, M. C., and Hansky, J. (1972). British Medical Fournal, 1, 209.

Moore, T. C. and Hume, D. M. (1969). Annals of Surgery, 170, 1

Multicentre Pilot Study (1967). Lancet, 1, 291

Schupak, E., and Ferayorni, J. (1968). American fournal of Digestive Diseases, 13,747 .

Wiener, S. N., Vertes, V., and Shapiro, H. (1969). Radiology, 92, 110

\section{PRELIMINARY COMMUNICATIONS}

\section{Rheumatoid Arthritis, Rheumatoid Factor, and Tests for Australia or Hepatitis-associated Antigen}

\author{
C. J. BURRELL, J. D. DICKSON, H. GERBER, \\ J. N. MCCORMICK, B. P. MARMION
}

British Medical fournal, 1972, 4, 23-24

\section{Summary}

False-positive results in tests for hepatitic-associated antigen using latex agglutination techniques may be due to rheumatoid factor in the serum. Possibly the use of IgM antibody in preparing the latex particles might

Department of Bacteriology, Edinburgh University Medical School, Edinburgh

C. J. BURRELL, M.B., PH.D., Lecturer

J. D. DICKSON, F.I.M.L.T., Chief Technician

B. P. MARMION, M.D., F.R.C.PATH., Professor

Rheumatic Diseases Unit, Northern General Hospital, Edinburgh H. GERBER, Technician

J. N. MCCORMICK, M.B., CH.B., Consultant Physician diminish the occurrence of such reactions. No evidence was found for a relation between rheumatoid arthritis and a significant incidence of hepatitis-associated antigen detectable by countercurrent immunoelectro-osmophoresis.

\section{Introduction}

The recently described latex agglutination test for the detection of Australia or hepatitis-associated antigen (H.A.A.) (Leach and Ruck, 1971; Fritz and Rivers, 1972) has been claimed to have advantages of speed and sensitivity over many currently used techniques. In this test latex particles coated with guinea-pig anti-H.A.A. whole serum or globulin fraction are agglutinated by H.A.A.-containing sera but not by normal sera. A variable incidence of false-positive results, however, has hindered widespread application of the method (Banatvala et al., 1971; Cossart et al., 1972). Because the H.A.A. latex test is similar in principle to the latex test for rheumatoid factor, in which particles coated with human $\gamma$-globulin are agglutinated by sera containing rheumatoid factor (Singer and Plotz, 1956; Valkenburg, 1963), we have examined sera from patients with rheumatoid arthritis in tests with two commercially available H.A.A. latex agglutination kits. Evidence is now presented that falsepositive results in this test can be due to the presence of rheuma- 